Portland State University

PDXScholar

\title{
A Descriptive Study of Educational Background, Contraceptive Knowledge, and Choice of Agency Among Selected Girls 18 Years Old and Under Seeking an Abortion at the University of Oregon Medical School
}

\author{
Carol A. Carter \\ Portland State University \\ Lititia J. Kirk \\ Portland State University \\ Jane F. Ogier \\ Portland State University
}

Follow this and additional works at: https://pdxscholar.library.pdx.edu/open_access_etds

Part of the Health Services Research Commons, and the Social Work Commons Let us know how access to this document benefits you.

\section{Recommended Citation}

Carter, Carol A.; Kirk, Lititia J.; and Ogier, Jane F., "A Descriptive Study of Educational Background, Contraceptive Knowledge, and Choice of Agency Among Selected Girls 18 Years Old and Under Seeking an Abortion at the University of Oregon Medical School" (1972). Dissertations and Theses. Paper 1561. https://doi.org/10.15760/etd.1560

This Thesis is brought to you for free and open access. It has been accepted for inclusion in Dissertations and Theses by an authorized administrator of PDXScholar. Please contact us if we can make this document more accessible: pdxscholar@pdx.edu. 
A DESCRIPTIVE STUDY OF EDUCATIONAL BACKGROUND, CONTRACEPTIVE KNOWLEDGE, AND CHOICE OF AGENCY AMONG SELECTED GIRLS 18 YEARS OLD AND UNDER SEEKING AN ABORTION AT THE UNIVERSITY OF OREGON MEDICAL SCHOOL

CAROL A. CARTER

LITITIA J. KIRK

JANE F. OGIER*

A practicum submitted in partial fulfillment of the requirements for the degree of MASTER OF SOCIAL WORK

Portland State University

1972 
We wish to acknowledge and thank the following persons who contributed so much to this study: Dr. Burritt W. Newton, Department of Obstetrics and Gynecology, University of Oregon Medical School, who sanctioned our conducting the research at the Medical School; Dr. Quentin D. Clarkson, Associate Professor of Statistics, School of Social Work, Portland State University, and June Dunn, Director, Maternal and Child Health Training Project, Portland State University, for giving us so much of their time, counsel, and guidance as well as for their critical readings of the various drafts of the manuscript; Leslie W. Hunter, Director of Social Service, University of Oregon Medical School, and his staff for their cooperation.

Our special thanks and appreciation are extended to the 40 anonymous girls who were the subjects of our research and whose cooperation made this study possible. 
TABLE OF CONTENTS

PAGE

ACKNOWLEDGMENT . . . . . . . . . . . . . . i ii

CHAPTER

I INTRODUCTION .................. 1

Population . . . . . . . . . . . . 2

Methodology . . . . . . . . . . 3

II FINDINGS ................. 6

III DISCUSSION . . . . . . . . . . . . 16

A. Population Characteristics...... 16

B. Familial Factors .. . . . . . . 17

C. Degree and Source of Knowledge

of Birth Control . . . . . . 18

D. Use of Contraceptive Methods ...... . 21

E. Sources Affecting Contact with Clinic . . 24

IV REVIEW OF LITERATURE . . . . . . . . . 26

A. Population Characteristics ....... 31

B. Degree and Source of Knowledge of

Birth Control .. . . . . . . 34

C. Use of Contraceptive Methods . . . . . 38

D. Sources Affecting Contact With Clinic . . 40 .. 
V RECOMENDATIONS . . . . . . . . . . . 44

VI CONCLUSIONS . . . . . . . . . . . . . . 46 46

LIST OF FOOTNOTED REFERENCES . . . . . . . . 48

LIST OF RELATED READINGS . . . . . . . . . 50

APPENDIX I . . . . . . . . . . . 52

APPENDIX II .............. 56 
CHAPTER I

INTRODUCTION

This study was conducted at the University of Oregon Medical School located in Portland, Oregon. This school has performed many abortions since Oregon liberalized its abortion law in 1969.1 In Oregon in 1968 before the abortion law was changed there were 238 abortions performed, $35 \%$ of these were for women under the age of 19. During 1971 there were 6,997 abortions of these 2,625 were for girls of age 19 and younger. 2

A common interest was held by those involved in this study concerning girls 18 and younger who were receiving abortions, and how knowledgeable they were about contraceptives. The study was also done with the intention that it might be a contribution to a dialogue on developing more information on girls of this age group who are receiving abortions. An exploratory design was used to gain descriptive information. This seemed the most appropriate research method for gathering attitudinal data from a sma11 sample population. It was

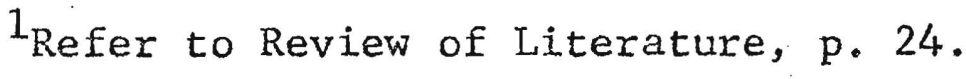

${ }^{2}$ Vital Statistic Section of Oregon State Health
} Division, 1971. 
important that the research design allow objective exploration of all the possible interpretations of the data. At the time information was being gathered for this study there were relatively few studies that had been conducted on abortions for girls under 18 years of age.

The Social Service Department of the University of Oregon Medical School and the Obstetrics-Gynecology Department were interested in finding out more information about the young girls that were coming to the hospital for the purpose of obtaining an abortion. Dr. Burritt Newton, Associate Professor in the Department of Obstetrics-Gynecology, particularly wanted information regarding the following: 1) What alternatives the girls seeking abortion at the University of Oregon Medical School would have considered in solving their pregnancy problem if they had not received an abortion at the Medical School? 2) Was there a community system of referral apparent in the method by which these girls applied at the Medical School clinic? 3) What other abortion resources could be specifically named by these girls.

We as a group were looking for insights into the nature of the problems and behavior of these young girls. POPULATION

The girls participating in this study had all been 
definitely accepted to receive an abortion at the Medical School. Al1 the girls were 18 years or younger. There was no stipulation as to residence, except for the agency requirement that the aboxtion service was available for Oregon residents only. (See Appendix II). This residency requirement is also stated in the Oregon abortion 1aw mentioned above.

Abortion services are given by both public and private clinics within the Medical School Institution. At the Medical School faculty members have a working agreement that a percentage of their time can be devoted to private practice, thus the two clinics. The eligibility difference between these two clinics is determined by a patient's financial resources. Those girls from the public clinic were of a low-income status, unable to afford private care although not receiving welfare. The sample selection, however, was not determined by this difference-subjects were interviewed as they came in regardless of which clinic they were attending.

\section{METHODOLOGY}

Subjects were interviewed on weekdays during office hours before the abortion operation occurred, according to the availability of the interviewers. This study began on July 14, 1971, running for 14 weeks, terminating October 13, 1971. Arrangements were made to give the interview before 
the doctor's examination and before an informational group session because we were interested in their contraceptive knowledge. In these sessions the girls received information about the abortion procedure and types of contraception. We were able to interview all but five girls before this informational group session. This may have slightly influenced actual knowledge about listed contraceptive methods, however it would not have affected the information gathered about contraceptive methods used.

The girls were told about the study and why the hospital was interested in gaining this information, they then decided whether they wanted to participate. Of the girls asked, none refused. They were assured that their names would in no way be attached to the questionnaire. Because of the ages of the girls involved it was felt that an oral interview should accompany the questionnaire. This was to lessen misinterpretation of any questions. Interviewers recorded the responses to the questions in order to eliminate possible written errors by those being interviewed.

The interviews were conducted for the most part by the three practicum members. When this was not possible a social service secretary administered the questionnaire. All interviewers participated in training discussions for the purpose of standardizing their understanding the meaning of each 
question. The procedure was to read the question to the participant and check the appropriate response on the questionnaire. The interviewer was responsible for clarifying any misunderstanding. The questionnaire was administered individually in an isolated room. The interview took from 10 to 20 minutes. The girls were given an opportunity to ask questions about the questionnaire. They were thanked for their information and participation: 


\section{CHAPTER II}

\section{FINDINGS}

The basic aim of the finding information is to provide a general description of the abortion service population; particularly females 18 years old and under. The following information shows the results of the data as it is presented in the questionnaire. (See Appendix I).

TABLE I

Various age groups composing study are as follows:

$$
\begin{aligned}
& 12 \text { to } 13 \text { years . . . } 1 \\
& 14 \text { to } 15 \text { years ... } 6 \\
& 16 \text { to } 17 \text { years . . . .15 } \\
& 18 \text { years . . . } 18
\end{aligned}
$$

Because of the obvious gap between 16 years and older compared to under 16 years, we found our comparisons to be much clearer, if the age category is simplified by dividing the categories into two major groups--(1) 16 years and older; (2) under 16 years.

TABLE II

$$
\begin{aligned}
& 16 \text { to } 18 \text { years } \cdot . \cdot 82.5 \% \\
& \text { Under } 16 \text { years... } 17.5 \%
\end{aligned}
$$

Of the 40 subjects interviewed, there is a much greater percentage of older girls seeking abortion service. 
TABLE III

Subjects presently enrolled in school are as follows:

$$
\begin{aligned}
& \text { YES: } 24--60 \% \\
& \text { NO: } 16--40 \% \text { (Of these } 16,13 \text { completed } \\
& \text { the } 11 \text { th or } 12 \text { th grades) }
\end{aligned}
$$

TABLE IV

Highest grade completed by subjects:

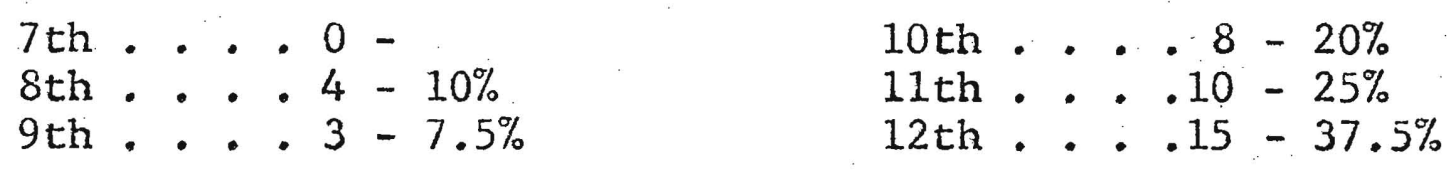

In describing later comparisons we again found it to be clearex if we divided the categories into two major groups; (1) Those who had not completed 11 th or. 12 th grades of education. (2) Those who have completed these grades.

da:

\section{TABLE $V$}

Not completed 11 th or 12 th . . $15-37.5 \%$ Completed 11th or 12 th . . $25-62.5 \%$

There is a much higher percentage of girls in or having completed 11 th and 12 th grades.

\section{TABLE VI}

Subjects school and its location: (See Appendix II). Two of the forty subjects gave no response. The remaining 38 responses indicated a wide variety of schools throughout the state.

16 subjects, or $42.1 \%$ were from the Portland area, 


\section{TABLE VI (continued)}

including Gresham, Beaverton, and Tigard.

The girls did not come from one area in particular-of the total 38, only 2 schools were mentioned twice.

TABLE VII

Parental Education

Mothers Fathers

a) Did not graduate from high school

18

15

b) High school graduates

c) Attended college

$8 \quad 13$

d) College graduates

8

e) Post-graduates

$5 \quad 2$

$1 \quad 2$

To facilitate clarification in comparing this category with other categories, we divided the responses into two major groups:

\section{TABLE VIII}

\section{Mothers Fathers}

1) Those who did not graduate from college

2) Those who did graduate from college

$6(15 \%) \quad 4(10 \%)$

Of the 40 subjects studied a much greater number stated that their parents did not graduate from college.

TABIE IX

Previous abortions within the immediate family:

$$
\begin{aligned}
& \text { YES - 5. . } 12.5 \% \\
& \text { NO }-32 \cdots 80 \% \\
& \text { DK - } 3 . .7 .5 \%
\end{aligned}
$$




\section{TABIE IX (continued)}

There is a very low number of subjects who stated there had been abortions in the family prior to the present one.

\section{TABLE $X$}

Subject!'s knowledge of birth control methods and a comparison of how many of those responses used these methods:

Withdrawal

Condom

Pi11

Rhythm

Foam, jelly

IUD

Diaphragm

Douching

Tubes tied

Vasectomy $\frac{\text { Know }}{13}-\frac{\text { About }}{32.5 \%}$

$31 \quad 77.5 \%$

$39 \quad 97.5 \%$

$17 \quad 42.5 \%$

26

26

27

14

20

19

15 Never used $\frac{\text { Use }}{10 \quad 77 \%}$

11. $35.5 \%$

11. $28.2 \%$

$6 \quad 35.3 \%$

$0 \quad 0.0 \%$

$1 \quad 3.85 \%$

$0 \quad 0.0 \%$

$3 \quad 21.4 \%$

0

0

The pill received the highest number of responses concerning knowledge. The number of subjects having used a particular birth control method is not as great as the number who knew about the method.

\section{TABLE XI}

For further comparisons, the knowledge group was also converted into a scale for clarification:

\section{KNOWLEDGE SCALE: Number of Methods Known}

9 - 10 Very knowledgeable

7 - 8 Knowledgeable

4 - 6 Average
$1127.5 \%$ of total subjects $6 \quad 15 \%$

$13 \quad 32.5 \%$ 


\section{TABLE XI (continued)}
2 - 3 Below average
$922.5 \%$
0 - 1 Little or no knowledge
$12.5 \%$

Of the 39 subjects that knew at least 2 methods of birth control, $15,38.5 \%$ never used those methods.

\section{TABLE XII}

Sources of information about birth control:

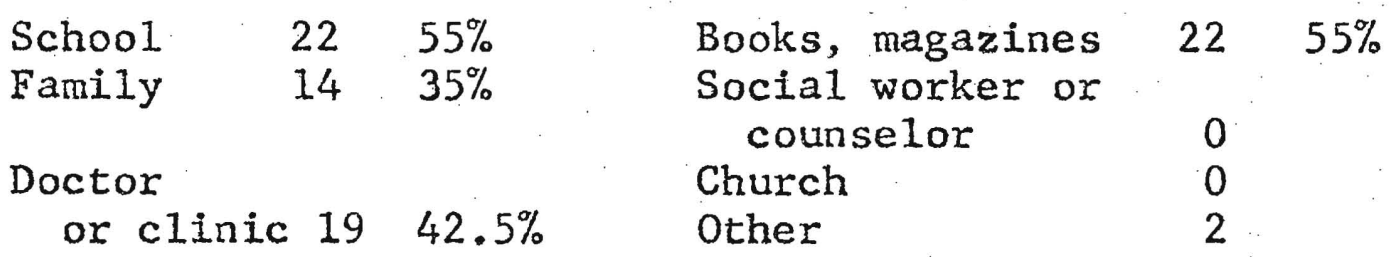

The greatest source of information was through the school and books.

\section{TABLE XIII}

Subjects attempting to obtain birth control methods which must be purchased or secured from a doctor or clinic:

$$
\begin{aligned}
& \text { YES }-18 \cdot-\cdot \cdot 45 \% \\
& \text { NO }-22 \cdot \cdot 55 \%
\end{aligned}
$$

Those 18 subjects who specified where they made the attempt were quite varied in their responses. More specifically: See Table XIV.

\section{TABLE XIV}

$7-38.9 \%$ Ss turned to Planned Parenthood or Family Planning.

$5-27.8 \%$ Ss turned to private doctors. 
TABLE XV

Subjects using contraceptive methods:

$$
\begin{aligned}
& \text { YES - } 18 \\
& \text { NO }-26
\end{aligned}
$$

Subjects not using contraceptive methods specifying why not:

Of the emotional reasons:

$\begin{array}{lrc}\text { Too silly } & 1 & 3.82 \% \\ \text { Not romantic } & 1 & 3.82 \% \\ \text { Too embarrassed } & 11 & 42.3 \% \\ \text { Fear of disease } & 2 & 7.7 \% \\ \text { Other } & 7 & 26.45 \%\end{array}$

Of 26 Ss not using birth control:

$$
\begin{aligned}
& \text { DNA - } 18 \\
& N R=2
\end{aligned}
$$

Of the factual reasons:

Did not understand

$$
\text { directions } \quad 1.3 .82 \%
$$

Too new, unconventional

Parents disapproved $12 \quad 46.2 \%$

Too expensive

$$
\begin{aligned}
& \text { DNA - } 18 \\
& \text { NR - } 2
\end{aligned}
$$

Too embarrassed and parents' disapproval seem to be the two most influential factors in not using birth control devices.

Planning to use contraceptives in the future:

$$
\begin{aligned}
& \text { YES - 34. } \cdot 85 \% \\
& \text { NO }-3:-7.5 \% \\
& \text { DK }-3 .:-7.5 \%
\end{aligned}
$$




\section{TABLE XVI (continued)}

After becoming pregnant and coming to the clinic seeking an abortion, a much greater number of subjects do plan on using some type of birth control device than the number of subjects that used one before the present situation.

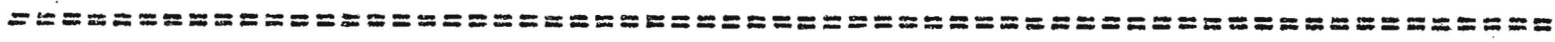

\section{TABLE XVII}

Sources of information about this clinic:

\begin{tabular}{|c|c|c|c|c|}
\hline $\begin{array}{l}\text { Family } \\
\text { Friends } \\
\text { School }\end{array}$ & $\begin{array}{lr}6 & 15 \% \\
5 & 12.5 \% \\
0 & \end{array}$ & $\begin{array}{l}\text { Planned Parenthood } \\
\text { Family Planning } \\
\text { Other agency or }\end{array}$ & 17 & $17.5 \%$ \\
\hline & & $\begin{array}{l}\text { clinic } \\
\text { Other }\end{array}$ & 22 & $\begin{array}{r}55 \% \\
5 \%\end{array}$ \\
\hline
\end{tabular}

The greatest number of subjects learned of this clinic through various other agencies or doctors.

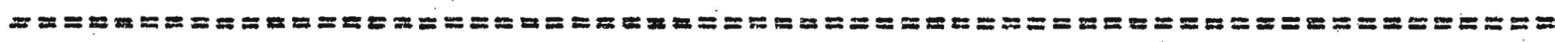

\section{TABLE XVIII}

Who actually influenced their decision to approach this clinic:

$\begin{array}{lrrlrr}\text { Family } & 12 & 30 \% & & \text { Planned Parenthood or } & \\ \text { Friends } & 4 & 10 \% & & \text { Family Planning } \\ \text { School } & & \text { Other agency or } & 6 & 15 \% \\ & & \text { professional } & 24 & 60 \% \\ & & \text { Other } & 6 & 15 \%\end{array}$

Other agencies and professionals are the most influential referral source of the 40 subjects.

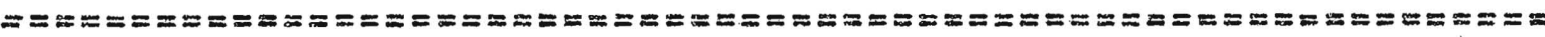

TABLE XIX

What would be done if this clinic did not give them an abortion:

Keep baby $7.17 .5 \%$




\section{TABLE XIX (continued)}

Go to another clinic or doctor $25 \quad 62.5 \%$

Give up baby for adoption $6.15 \%$

Have illegal abortion $\quad 2 \quad 5 \%$

The largest number of subjects would turn to another clinic for help.

SIGNIFICANT COMPARISONS

TABLE XX

Ss age compared to contraceptive knowledge:

Under 16

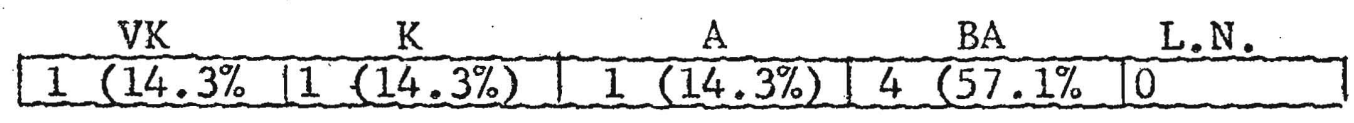

16 to 18

years

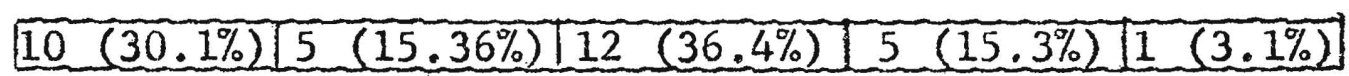

Shows a tendency that an increase in age relates to an increase in contraceptive knowledge.

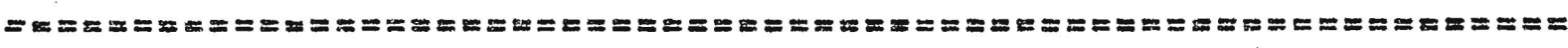

TABLE XXI

Ss education compared to contraceptive knowledge:

Less than

11 th

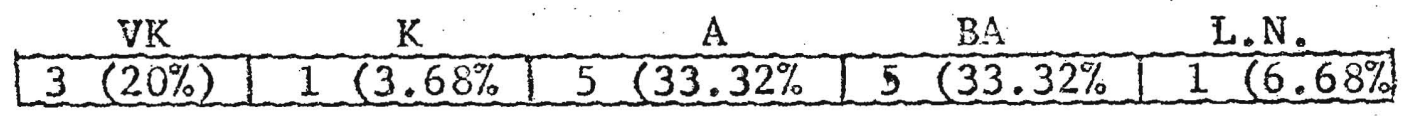

Completed

11th or

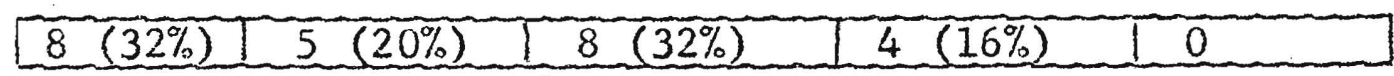

12 th

grades

Shows a tendency that an increase in education relates to an increase in contraceptive knowledge. 


\section{TABLE XXII}

Same objective as Table I only with broader groupings-age compared with knowledgeable vs. not knowledgeable:

Under 16 years

16 to 18 years
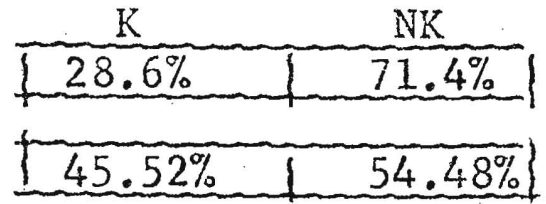

Findings are the same as in Table $I$; shows a tendency that an increase in age relates to an increase in contraceptive knowledge.

\section{TABLE XXIII}

Same objective as Table II only with broader groupings-education compared with knowledgeable vs. no knowledgeable:

Less than 11 th grade

\begin{tabular}{|l|l|}
\hline & $\mathrm{NK}$ \\
\hline $26.68 \%$ & $73.32 \%$ \\
\hline
\end{tabular}

Completed 11th or 12 th grades

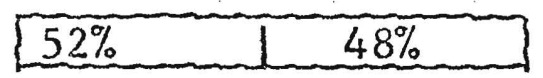

Shows a tendency that an increase in education relates to an increase in contraceptive knowledge.

Comparison of Parents' education (graduated from college [HI] vs. not graduated from college [LO/) with subject's age at time of pregnancy (Young--1ess than 16 years vs. $01 d--16$ to 18 years):

Mother's

Education

\begin{tabular}{|c|c|c|}
\hline & Young & O1d \\
\hline LO & $7(100 \%)$ & $27(81.9 \%)$ \\
\hline HI & 0 & $6(18.1 \%)$ \\
\hline
\end{tabular}

All of the young subjects had mother's with low educational background. All mothers with higher educations had daughters falling into the older age category. 
TABLE XXV

Same as above, but with father's education instead:

Father's

Education

\begin{tabular}{|c|c|c|}
\multicolumn{1}{c}{ Young } & Old \\
\hline LO & $7(100 \%)$ & $28(84.7 \%)$ \\
\hline HI & 0 & $5(15.3 \%)$ \\
\hline
\end{tabular}

A1I of the young subjects had fathers with low educational background. All fathers with higher educations had daughters falling into the older age category.

TABLE XXVI

Comparison of parents' educational background with subject's contraceptive knowledge. Mother's education:

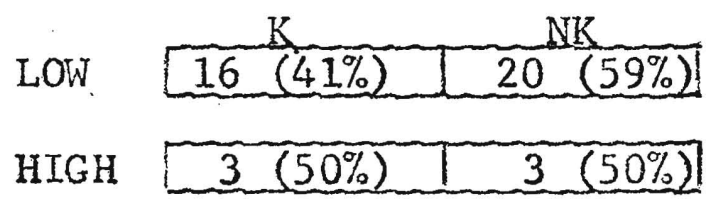

Father's education:

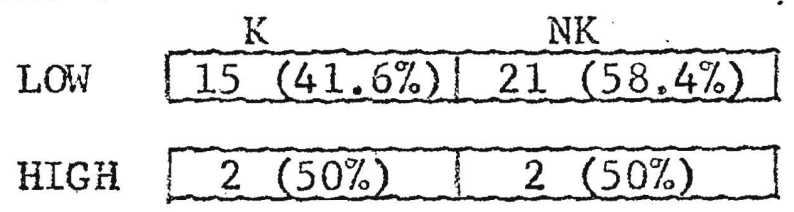

In both instances there seems to be very little difference between subject's knowledge of contraceptives and a parent's level of education. 
CHAPTER III

\section{DISCUSSION}

There are five major areas of particular importance to this study:

\section{A. Population Characteristics:}

The age factor should be mentioned in the discussion, if only for the simple reason that it was the basis upon which the study sample was selected. About the only concrete observation which can be made is that there is quite a prevalence of 18-year olds (45\%) receiving abortion services at this clinic, (see Table I). In comparison, the younger girls, 15 years and under, are represented in the sample by a percentage of only $17.5 \%$, whereas the entire category of older girls, 16 years and over, comprise the remainder of 82.5 percent. This then makes up the age distribution of the study. Some possible reasons or hypotheses for such a distinction distribution between the two groupings are introduced in the chapter on conclusions and recommendations. It also occurs to us that a fair amount of 18-year old: girls were out of school, and we wonder if being out of school has any influence toward a greater tendency to become pregnant. 
The population characteristics data also indicated, as shown in Table VI, that the greater number of girls are from outside the Portland area. This could illustrate the lack of facilities for families of this income level elsewhere in the state, a desire to keep this procedure secret, or a lack of confidence in the abortion services within their own community. From a medical standpoint, there may be more risk with younger girls, thus there might be a tendency for local doctors to refer the patient to a medical center with more experience in performing abortions.

\section{B. Familial Factors:}

There was a prevalence of parents having no college degree (mothers--85\% and fathers--90\%), and we would wonder if this is again related to the large number of low income individuals who are received by the Medical School.

One interesting point is that of the parents who had college degrees, all had daughters in the older age (16-18) grouping (Tables XXIV and XXV). In this study younger girls requesting abortion services had parents with less education. Another factor in this category is Table IX, previous abortions within the immediate family. The study found $12.5 \%$ of the girls were aware of other family members receiving abortions, and another $7.5 \%$ indicated they did not know. The 
fact that they were unsure seems to suggest the possibility that an abortion did occur at some time. Although general population statistics are extremely difficult to find in relation to this question, it seems to the researchers the incident of previous abortions within the family may be more common in the study sample than it is within the general population.

C. Degree and Source of Knowledge of Birth Contro1:

As shown in Table XII in this study, schools and reading material are leaders in informing adolescents of birth control methods. The next most common sources include doctors and clinics. It was interesting to the researchers that families did not play the important role in providing birth control information. Only 14 girls received any information at all from their family. From these results it appears there is active involvement in providing birth control information shared by many facets of the community. In Table $X 75 \%$ of the sample knew of at least four birth control methods. (See Table $\mathrm{X}$ results for further discussion). In fact $100 \%$ of the sample did know something about birth control methods. Ninety-seven percent of the sample knew about the contraceptive pi11, and $65 \%$ knew of the Intrauterine device, which are the two most effective means of preventing pregnancy. 
The following are failure rates per 100 women years for the methods mentioned in this discussion:

Oral Contraceptives

IUD

Coitus-interruptus

(withdrawal)

Condom

Rhythm

FAILURE RATE:

Theoretical Effectiveness

(Constant users)

$$
0.1-1.0
$$

$1-3$

$15-25$

15
USE

EFFECTIVENESS

(Actual users)

$5-25$

$3-10$

Use-effectiveness refers to the chances of failure involving the variable of human error in following strict instructions for ultimate efficacy. For example, the condom has a fairly high theoretical rate of effectiveness, approximately $95 \%$, however, there are certain essential precautions that are so frequently overlooked or ignored that the useeffectiveness dropped to a possible $75 \%$.*

*Contraceptive Technology, The Emory University Family Planning Program. Department of Gynecology and Obstetrics. Emory University School of Medicine. Atlanta, Georgia, 1971.

I

These examples of the girls' awareness of contraceptive methods might illustrate the comprehensive exposure birth control information is gaining in the adolescent population. However, the lack of use of these methods might indicate knowledge gaps in educating adolescents for actual use of these 
devices. We did not gain information about which methods these girls considered safe, and thus we did not test their application knowledge.

The information on contraceptive knowledge was perhaps the most significant finding in this study, particularly in comparing contraceptive information with contraceptive utilization. We had particular interest in the data on the methods of withdrawal, foam or jelly, and the diaphragm shown in Table $\mathrm{x}$. Withdrawal is in a great respect more of a responsibility of the boy rather than the girl. In this light, we feel it possible that the boy may be putting this method to use without the girl being aware of it. If this is in fact what happens in many cases, then knowledge and use of this method would be greater. The importance of the boy's awareness and responsibility in the use and effectiveness of birth control methods is alluded to in the review of literature The use of foam or jelly was not used at all by the girls in this study. The researchers found this quite interesting in view of the fact that $65 \%$ of the sample "knew about" these spermicide methods. These methods are easily accessible in any drug store, and are not unreasonably priced. Yet, they were not used at $a 11$ as noted in the findings. We wonder if perhaps the way in which information on the use of foam and jelly is conveyed by schools, doctors, etc. is not as 
effective or assuring as it might be. Without adequate demonstration, girls may think they are messy, or have unappealing odors, or have an uncomfortable texture, or may be irritating before, during, or after usage. We feel that much confusion may be clarified through more in-depth techniques of education. There was also a great number of girls in the study (Table $\mathrm{X}, 67.5 \%$ ) who knew about the diaphragm, but again none of them put this method to use: One reason for this inconsistency that we feel might be influencing the girls is the idea that the diaphragm is not modern, it is a method that even "mother used." The diaphragm must also be fitted by a physician which could make utilization even less desireable.

D. Use of Contraceptive Methods:

An important point is that the knowledge that is conveyed is not put to use. As shown in Table $X$ the three most frequently used methods are withdrawal, the condom, and the rhythm method. Yet these are the lease effective in preventing impregnation. Reasons for their popularity may include that they do not require following complicated instructions; they are easy to obtain and use, i.e., a doctor need not be involved; there is little preparation necessary; there is less planning ahead; and there is little expense. In a broader sense it is apparent that education is 
the most important factor in creating an informed attitude on the part of adolescent girls toward pregnancy and abortions. The second most important factor is that this knowledge is acquired more likely by being exposed to an educational process rather than more personalized instruction and help as seen in Table XII (school and reading material had the greatest percentage as sources of birth control information. In a study done in Newark, New Jersey, many girls who didn't want to become pregnant and had access to birth control devices and knowledge did not use them. ${ }^{3}$ It seems to us that general knowledge is not the same as useable knowledge. Table X shows that $37.5 \%$ of the sample had never used birth control methods. This could imply that although there is contact with authority and informative figures, there must be something dubious about the situation, because the girls who could use the information are not following through.

In searching for substantive research in this area one interesting article described where Detroit high school student delegates at the conference at Wayne State University were asked their opinions on sex education. They mentioned that the emphasis of the teacher in charge of this subject

3 Dolores Malo-Juvera, "What Pregnant Teenagers Know About Sex," Nursing Qutlook, Vo1. 18, Nov. 1970, pp. 32-35. 
should not be on who could teach about sex, but on the kind of person. (This feeling was applicable to parents also.) They felt that skill and personality were the major factors to consider. They felt someone who was warm, responsive, not shy but open-minded would be desirable. Some felt that this person should be specially trained for this subject. They also indicated particular areas of interest that were not covered by sex education in the schools, such as premarital intercourse homosexuality. They did not want a course on morality. 4

This is further presented in the current study by Table XV. There is a very high percentage $(42.3 \%)$ of girls saying that the emotional reason they did not use contraceptives was due to feeling too embarrassed. The deeper psychological implications underlying this feeling are vast, but the important point is that mere knowledge or information has not adequately alleviated the very uncomfortable feeling of applying the knowledge. Another aspect is that of the factual reasons (Table XV) $46.2 \%$ stated that parental disapproval was a major reason for not using contraceptives. Again the tendency is shown that widespread knowledge is not the final solution to the problem of unwanted pregnancy. Presentation

${ }^{4}$ Gertrude B. Couch, "Youth Looks at Sex," The Journa1 of Social Health. Vol. XXXVII, 1967, pp. 333-338. 
of facts does not satisfactorily alter moral and attitudinal pressures. The situation seems to be in many cases that by actually going out and obtaining contraceptive devices which entail planning, physical examinations, etc., a girl is admitting or submitting to what spciety still lauds as imoral activities; and that she is pre-meditating such activities.

E. Sources Affecting Contact with Clinic:

Both Tables XVII and XVIII indicate that the services offered by the Medical School are well known by clinics and professionals throughout the State. The tables also show that the schools, having the highest percentage for giving birth control information, do not attempt to go beyond the subject of prevention. The girls received no information nor sought assistance for dealing with the problem if and when it occurred. Underlying attitudes seem inconsistent with the new advocacy for less traditionally narrow education.

It is also evident from Table XIX that most girls (62.5\%) would go elsewhere had the Medical School clinic turned them down. This finding in comparison to the $5 \%$ who said they would have an illegal abortion, shows that most giris were aware that these services are legal and available. The large percentage that answered they would go to another clinic aiso indicates that the Medical School was one of the 
first possibilities approached by these girls.

Table XIX could also indicate that these girls are saying they would actively seek an abortion, if this service were not available. The fact that there aren't too many "elsewhere," i.e., hospitals or doctors who would perform an abortion within these girls' financial capabilities, might make the going elsewhere response wishful thinking. The researchers also feel that there could be a distinct unwillingness to choose the illegal abortion response when a legal, more acceptable alternative is given to them--i.e., going elsewhere. 
CHAPTER IV

\section{REVIEW OF LITERATURE}

The review of literature covers the problems of teenage pregnancy, an overview of the medical and legislative changes in the United States regarding therapeutic abortion, and Oregon's abortion law. The remainder of this section will deal with material applicable to our study namely A) population characteristics, B) degree and source of knowledge of birth control, C) use of contraceptive methods, and D) sources affecting contact with the clinic. There has been much written within the past few years concerning the topics of teenage pregnancy, sexual activity, sex education, and abortion. However, we did not find any descriptive studies pertaining directly to girls 18 years old and under seeking therapeutic abortions.

Currently there are 900,000 identified pregnant girls age nineteen and under in this country. 5 Because of the alarming numbers, there has been an increased amount of interest focused on the problems of the pregnant school girl.

5 Earl Warren Hall, Social and Health Needs In Childhood and Adolescence (California, 1972), p. 116 . 
and repeat pregnancy.

There are various alternatives available to pregnant teenage girls. They include carrying the baby to full term and keeping the child, or giving it up for adoption or foster care. The other alternative recently made available through legislation is termination through abortion, which is the concern of this study. Rapid changes in abortion legislation and medical practice have been taking place in the United States. Large numbers of legal abortions have been handled in 1970 and the first half of 1971. Medical information indicates that one of the safest ways to terminate a pregnancy is by therapeutic abortion during the first 10 to 12 weeks of pregnancy. The review of literature indicates that states have approved therapeutic abortion procedures in a variety of supervised settings from outpatient clinics unattached to hospitals to strictly supervised hospitalization requirements. The terminations are performed by a procedure called "D\&C" (dilatation and curettage) which involves scraping the womb with a curette and or vacuum aspiration, but without general anaesthetic. Emphasis is placed on future use of contraception. Between 16-22 weeks, pregnancy is terminated by saline abortion which involves a saline injection into the womb to induce labor. Changes in legislation have occurred more rapidly in the United States than in the United Kingdom. By June 1970, 
4 states had virtually repealed all statutes. regulating termination of pregnancy, 17 states had reformed their abortion laws, only 4 states did not have repeal or reform bills before their legislation. Because many of the states have liberalized their abortion laws, "American women now should be able to obtain safe, competent medical abortion in clean, hygenic surroundings."7 Regulations vary from state to state regarding residency requirements, reasons for requesting abortion, and termination period. Regarding the incidence, the Center for Disease Contro1 in the United States Department of Health, Education, and Welfare has gathered statistics covering part or al1 of 17 states, with a variety of repeal, reform and restrictive legislation. In 1970 there were 1,213,919 live births and 177,113 legal abortions, giving a ratio of legal abortions to live births of 14.6 per $100 .^{8}$ It is difficult to establish an accurate ratio because of under-reporting of legal abortions and some states do not disclose their statistics.

The distribution by age of reported legal abortions has been similar to that observed for live births. From

${ }^{7}$ George Langmyhr and Walter Rogers, Legal Abortion: A Guide for Women in the United States, (New York, 1970), p. 1.

${ }^{8}$ Malcolm Potts, "Legal Abortions in the U.S.A.: A Preliminary Assessment," The Lancet (September 18, 1971), p. 651. 
records of 76,759 terminations gathered by the Center for Disease Control the following statistics are given. 9

\begin{tabular}{cr} 
age & under 15 \\
under 20 & less $1 \%$ \\
$20-29$ & $25 \%$ \\
$40+$ & $50 \%$ \\
\hline
\end{tabular}

In 1969, Oregon Law 435.415 was passed 1iberalizing the previous law regarding therapeutic abortions. This law states:

Justifiable termination of pregnancy by a physician

(1) A physician is justified in terminating the pregnancy of an Oregon resident if he has reasonable grounds for believing that:

a) there is substantial risk that continuance of the pregnancy will greatly impair the physical or mental health of the mother;

b) the child would be born with serious physical or mental defect; or

c) the pregnancy resulted from felonious intercourse.

(2) In determining whether or not there is substantial risk under paragraph a) of subsection

(1) of this section, account may be taken of the mother's total environment, actual or reasonably foreseeable.

(3) A justifiable termination of a pregnancy shall be performed only by a physician in a hospital.

This liberalization affected the state hospitals particularly because of section (3) of ORS 435.475 which states that:

No hospital operated by this state or by a political subdivision in this state is authorized to adopt a policy of excluding or denying admission 
to any person seeking termination of a pregnancy under ORS $435.415 .10^{\circ}$

In 1971 the Vital Statistics Section of the Oregon

State Health Division reported 6,997 therapeutic abortions or 212.0 abortions to every 1,000 live births, ${ }^{11}$ or about one to five. The following table illustrates Oregon's age distribution of women who experienced therapeutic abortions from January to December, 1971.

$\begin{array}{lr}\text { age } & \text { tota1 } \\ \text { under 15 } & 108 \\ 15-19 & 2,625 \\ 20-24 & 2,300 \\ 25-29 & 912 \\ 30-34 & 559 \\ 35-39 & 351 \\ 40-44 & 133 \\ 45+ & 9\end{array}$

A. Population Characteristics

This section gives a comparison of several studies regarding age distribution of women who experienced abortion. Some mention is made regarding socioeconomic status, although such data was not directly pursued in the present study. In

10William Nathe and Ike Lacefield, Degree of Depression in Women Preceding Abortion at the University of Oregon Medical School, Graduate School of Social Work, Portland State University. Feb. 23, 1972, pp. 1 and 2.

1 Vital Statistics Section of the Oregon State Health Division, 1971. 
the review of literature, the largest group of women seeking abortion are between the ages of 16-21, 20-24, 20-29 depending on the individual study. For example, the Department of Obstetrics and Gynecology at the University of Colorado Medical Center reported the second year's experience with Colorado's revised abortion law. This includes the period from April 25, 1968 through April 24, 1969. There were 637 therapeutic abortions in the second year. The age breakdown is seen in the following table: ${ }^{12}$

$\begin{array}{cc}\text { age } & \% \\ \text { under 16 } & 12.6 \\ 16-21 & 40.5 \\ 22-35 & 35.6 \\ \text { over 35 } & 11.3\end{array}$

Legal abortions in New York State were reported from July 1 December 31, 1970. During this period there were 34,175 induced abortions, 21,568 of these were to state residents. A11 teens combined accounted for $21.8 \%$ of all abortions, second only to the 20-24 year old which accounted for the greatest proportion--almost $37 \% .13$

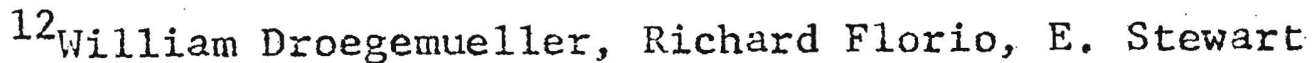
Taylor, "The Second Year's Experience With Colorado's Abortion Law," American Journal of Obstetrics and Gynecology CIX (March $15,1971)$, p. 957 .

13 Jean Pakter, David Harris, Frieda Nelson, "Surveillance of the Abortion Program in New York City: Preliminary Report," Clinical Obstetrics and Gynecology, XIV (July 1 December 31, 1970), p. 278 . 


$\begin{array}{rr}\text { age } & \% \\ \text { under } 15 & .3 \\ 15-19 & 21.5 \\ 20-24 & 36.9 \\ 25-29 & 19.3 \\ 30-34 & 11.9 \\ 40+ & 3\end{array}$

A Southern University reported that through a period of January 1964 to mid-July of 1970 a total of 91 requests for therapeutic abortion was submitted to the Committee on Therapeutic Abortions and Sterilization at the University Hospital. Seventy-one (78\%) of the applications received approval and 69 abortions were actually performed with two applicatns aborting spontaneouse1y. 14

$\begin{array}{cr}\text { age } & \text { 韭 } \\ 12-14 & 1 \\ 15-19 & 17 \\ 20-29 & 36 \\ 30-39 & 13 \\ 40+ & 4\end{array}$

The Vital Statistics Section of Oregon State Health Division (Oregon State Board of Health), indicates the largest group seeking abortion for 1971 are in the teens or very early twenties. The age differences may be explained by the different requirements of the law.

Literature indicates that women throughout all the

${ }^{14}$ George Fields and Frida Surawicz, "A Review of Therapeutic Abortions at a Southern University Hospita1," The Woman Physician, XXVI (August, 1971), p. 415. 
social strata face the dilemma of abortion. Here are two examples indicating the diversity of findings in studies. Cne illustrates that abortion is experienced by the lower income families and the other points to the middle and upper classes. Colorado reported that during the second year of the abortion 1aw, $52 \%$ of the patients had yearly family incomes of less than $\$ 6,000 .{ }^{15}$ The University of Kentucky Hospital reported that between the period of 1964 to midJuly 1970, 69 abortions were performed. The majority of applicants were single, white, in the mid-twenties. In regard to profession or education, the largest group were college students. Most women belonged to the middle or upper class and were well educated. Illegitimate pregnancy might affect a middle or upper class woman more severely than lower class women. 16

B. Degree and Source of Knowledge of Birth Control

The degree of sex knowledge which includes contraceptive knowledge varied from study to study. However, for the purpose of our study, we did not come across literature specifically relating to the degree of contraceptive knowledge.

\footnotetext{
15 Droegemue1ler, Op. Cit., 958. ${ }^{16}$ Fields, Op. Cit., 414.
} 
The following paragraphs give an illustration of the variation of sex knowledge.

A study was done in New York City of 48 recently delivered teenage mothers. It was found that the adolescents in this study were from urban ghetto communities and were poorly informed and misinformed about conception and contraception. 17

A study done at the Maternal and Infant Care Project in Newark, New Jersey on 100 pregnant adolescent girls 17 years old and under mentioned that most girls expressed amazement that impregnation occurred so quickly and easily. It was also learned that most girls began menstruation by age 12 . There was a correlation between this age and the age of coitus. The majority became sexually active two years after onset of menses. Most girls had relations with males at 14 and on an active weekly basis thereafter. Usually a period of one to two years of sexual activity preceded pregnancy. 18 Because of this data, it is felt that sex education should begin at a pre-adolescent level.

17 E1izabeth Conne11, and Linbania Jacobson, "Pregnancy, the Teenager and Sex Education," American Journal of Public Health, XI (September, 1971), $184 \widehat{5 .}$

18 Delores Malo-Juvera, "What Pregnant Teenagers Know About Sex," Nursing Outlook, XVIII (November, 1970), p. 33. 
A California survey reported a study of sexual knowledge, attitudes toward pregnancy and the role of parents during a girl's pregnancy. Their findings indicate that the unwed pregnant teenage girl possesses limited sex knowledge. Her pregnancy results from a feeling of deep emotional involvement with the putative father. The causes of unwed pregnancy are early dating, lack of proper sex education, and a lack of parental supervision. 19

A review of the literature indicates that the main sources of sex education are the family, friends or peer group, and the school. The order of significance of the three main sources varies with each individual study.

Some articles concerning sex education have found that students first learn about sex education from the family. However, studies have shown that parents never really get axound to meaningful discussions of sex with their children whether they are well educated or not. Some reasons include 1) they feel uncomfortable talking about this subject with their children, 2) they do not know how, and 3) they postpone it too long, so kids learn it from other sources. ${ }^{2}$ The majority of girls in the Newark, New Jersey study learned

$$
\begin{aligned}
& { }^{19} \text { Connel1, Op. Cit., } 1840 . \\
& 20 \text { William, William, "Sex Education for Parents, "The }
\end{aligned}
$$
Journal of School Health, XLI (October, 1971), p. 434. 
from their mothers, however, many mothers had distorted views of sex and were uncomfortable with their own sexuality. 21 When the family fails in sex education, students then turn to their peers, which is a second source of knowledge.

Other literature states that because sex is a peer approval activity, sex education is a peer phenomenon. 22 They seem to trust and identify with each other. However, their information is sometimes considered less valuable and there is little respect for what is "picked up on the streets" or "locker room talk."

The third most popular source that teenagers turn to for sex education is the schools. School systems are able to provide students adequate sex information, however, this is not the same as sex education. Foster, the author of an article entitled "Sex Information Vs. Sex Education: Implications For School Health," defines sex information as including the anatomy and physiology of the human body. He then describes sex education as incorporating insight into the social and psychic or emotional implications of sex. This also includes education in responsibility of contraception and morals. This should be done at an early age and continue

$$
\begin{aligned}
& 21_{\text {Juvera, Op. Cit., } 33 .} \\
& 22 \text { Ibid. }
\end{aligned}
$$


through high school. 23 Supportive data such as the Kirkendall and Calderwood study indicate that attitudes toward sex are formed at an early age. 24

C. Use of Contraceptive Methods

The following discussion involves the actual use of contraceptive methods. Studies $25,26,27$ tend to show that having knowledge of birth control does not guarantee utilization of birth control methods. One example of this is noted in the Schofield study.

The British data of Schofield (1965) suggest that initial pre-marital sex relations are typically unpremeditated and without contraception. Those with sex experience typically know of contraceptives but so did those without such experience. Contraception was a surprisingly infrequent phenomenon among those having sex relations, despite extensive fears of pregnancy. This study gives little evidence that knowledge of contraception encourages premarital sexual relations, or that fear of pregnancy is a major deterrent to such relations. 28

${ }^{23}$ Greg R. Foster, "Sex Information Vs. Sex Education: Implications for School Health," The Journal of School Health, XXXVII (May, 1967), p. 248.

24

Ibid.

25 Juvera, Op. Cit., p. 34.

26 David Claman, Barry Williams, and L. Wogan, "Reaction of Unmarried Girls to Pregnancy," Canadian Medica1 Association, CI (1969), p. 240.

27 Robert Young, "Sex, The Bible and Modern Man," The Journal of School Health, XL (December, 1970), p. 527.

28Edward Pohlman, The Psychology of Birth Planning (Massachusetts, 1969), p. 30 . 
Other literature suggests that there are certain reality problems that an individual must face when he or she tries to obtain contraceptives. A good discussion of these problems can be found in chapter 21 in The Psychology of Birth Planning.

This information indicates that:

Before a couple can use any of the more effective contraceptive methods, one partner must secure supplies, either from some other person or a storage receptacle. When supplies must be secured from another person-physician, social worker, pharmacist, merchant, relative or friend--some embarrassment often ensues. This is true of married people and may be especially true of unmarried individuals who need contraceptive protection. The latter may fear that they will be readily identified as unmarried and their plans exposed for social condemnation. Requesting contraceptives is an admission that one plans to have sexual relations; even for many married people with several children, overt admission of plans for intercourse is embarrassing. Furthermore, most contraceptives are used in contact with the genitals; the mutual knowledge of this fact, let alone explanations of how they are to be used, adds to the embarrassment. 29

Obtaining contraceptives may pose problems, also, in terms of individuals who may notice when contraceptives are secured. Other drug store customers may be watching the embarrassingly sex-related transaction. In almost any community of the world, the would-be user of contraception must calculate which others in the community will know, by observation or rumor, that he or she has visited the hut where pills are dispensed, the truck where vasectomies are performed, or the like. 30

The use of contraceptive methods varies according to the social class status. The data involving 400 odd

$$
\begin{aligned}
& { }^{29} \text { Ibid., } 356 . \\
& 30 \text { Ibid., } 357 .
\end{aligned}
$$


individuals in Rainwater's sample (1965, 201-205) seem consistent with his thesis that lower-class people are more reluctant to interfere with nature. Middle-class Protestants have an assured confident attitude toward contraception. They feel that sensible people are effective contraceptors and that contraceptive failure is something of a disgrace. Rainwater's upper-lower class respondents had a "hopeful-but-unsure" attitude towards contraception. The lower-class respondents showed less hopefulness and more wishfulness, less certainty and more pessimism. Fatalism is a common attitude. To summarize Rainwater's findings, "lower-class people often know about contraceptives in a verbal, impersonal sense; middle-class people tend to have a more personalized knowledge based on familiar and a successful experience. 31

D. Sources Affecting Contact With Clinic

Thus far the discussion has presented the problems of unwed pregnant teenagers and has alluted to their knowledge of contraceptive methods and its actual use. Let us now examine studies which discuss what action is being taken to help girls deal with the dilemma of unwed pregnancy. One effective means is the multidisciplinary clinic which seems

31 Ibid., p. 365. 
to be springing up around the country. The University of Oregon Medical School is one such clinic. Many of the nationwide clinics are geared to solely serving teenage unwed mothers and other young women 18 and under. This differs from the University of Oregon Medical School approach. Typically, according to descriptions in the literature, clinics are staffed by physicians, nurses, medical social workers and psychiatric consultants. These clinics provide comprehensive care to pregnant girls and after deliveries, offer birth control counseling and contraceptives, assistance in returning to school, as well as provide day care facilities for young children while the mother pursues educational or vocational interests. Some mothers of unwed pregnant daughters bring in older and younger siblings for contraceptives, to prevent the first unplanned pregnancy. Some clinics counsel with the unwed father as well as with the patient and parents. Studies show that these clinics reduce complications of pregnancy, decrease prematurity, a high percentage of girls accept some form of birth control, there is a significant reduction in incidence of repeat pregnancy, and more girls are returning to school. $32,33,34,35$

32 Philip M. Sarrel, Marshall Holley, and Gerald Anderson, "The Young Unwed Mother," Obstetrics and Gynecology, 
In surveying the literature we did not come across material directly relating to the sources by which a patient might be referred to a clinic. The clinics are generally available to the public at large. The manner by which patients made contact with a clinic varied greatly and we were not able to discern a pattern.

A final word of interest might be added regarding the impact of the modern abortion law. This may be indicative of what Oregon may experience. Colorado's liberalized abortion law has informed the general public of their rights and the availability of abortion. The Medical community faced the new law with great anxiety. Private hospitals and physicians were fearful of being labeled "abortion meccas" or "abortionists." Public hospitals were agitated by the resulting demands for abortions in regard to available beds, operating time, and disruption of teaching programs. Their resident staffs revolted over the amount of their time being spent in "unproductive" work-ups and procedures

YXXII (December, 1968), 741-747.

33 Juvera, Op.Cit., 32-35.

${ }^{34}$ Osofsky, Op. Cit., 958.

${ }^{35}$ Joseph Rauch, Lois Johnson, and Robert Burkett, "The Management of Adolescent Pregnancies," HSMHA Health Reports, IXXXVIII (January, 1971), pp. 66-73. 
with abortion patients. Both psychiatrists and gynecologists have felt that the task of scientifically evaluating the patients for abortion on psychiatric grounds to be impossible. It is difficult to differentiate social from psychiatric stress. 36 In reviewing the literature extensive reading was done. However, much of the readings are not addressed to the concerns of this study. For the convenience of others reading this report we will include all of the sources reviewed for this project.

36 Ibid. 


\section{CHAPTER V}

\section{RECOMMENDATIONS}

We feel there are two very important areas for future study. The first involves further investigation into the method of conveying birth control information and sex education to teenagers within Oregon's school systems. The current study has emphatically presented this as a crucial element in the growing pregnancy and abortion problem among adolescents.

A second area for further study concerns exploration of the adolescent boys' role in dealing with the problem. A study done at this same clinic by Ike Lacefield and Bill Nathe 37 showed that the kind of relationship the pregnant woman had with her male partner had an important affect on how she was able to cope with having an abortion. We feel it would be valuable to explore this type of relationship between the adolescent girl and her boyfriend in terms of the. utilization of birth control methods. Does the relationship with her sexual partner influence the adolescent girl's acceptance or selection of birth control methods? It should be noted that in this present study the methods of with drawal and the condom had a high frequency of use, indicating 
male participation in the birth control decision. What kind of role does the boy play in making the decision to use or not use birth control methods? How knowledgeable or aware is the boy concerning birth control and human sexuality?

In line with this recommendation, we found in the literature a study conducted by Claman, Williams, and Wogan which emphasizes the importance of male participation in sex education. They concluded:

It would seem obvious that the circumstances under which intercourse among young unmarried people usually occurs are those in which it is not reasonable to expect a girl to have come prepared with contraceptives or to have been on "the pi11." It is obvious also that the boy is usually the aggressor and the intender, so that if pregnancy is to be avoided during sexual contact between unmarried teenagers the responsibility for contraception must be primarily undertaken by the male. It is important that this be properly understood and that appropriate emphasis on the male role and responsibility be given in sex education. 38

We suspect that such a study may lead to evidence supporting the need for educating adolescent boys and developing a greater awareness and responsibility in considering consequences and repercussions of teenage pregnancy.

${ }^{38} \mathrm{Claman}$, Williams, and Wogan, "Reaction of Unmarried Girls to Pregnancy," Canadian Medical Association, Vol. 1 (1969), pp. 240-41. 
CHAPTER VI

CONCLUSIONS

The researchers feel that the single most significant finding involves that portion of the study concerning the girls' contraceptive knowledge and its utilization. The findings show that all of the girls have some awareness of the functions or existence of various birth control methods that are medically considered most effective. The fact that these girls requested abortions indicates that they did not want to become pregnant. Therefore, the reasons they did not use the most effective birth control methods or not take any precautions at a11, have to be more complex than just being aware of birth control. That is to say, emotional, social, and environmental factors seem very much a part of their decision to use birth control.

Our conclusion is based upon this inconsistency in that it points directly to the failure of the methods or techniques employed to educate these girls in the area of birth control and sex education. This applies particularly to the schools since they were primary sources of birth control information. 
As described in the discussion: Education is the single most important factor in creating an informed attitude on the part of adolescent girls concerning pregnancy and abortions. In considering the number of girls requesting abortions and the amount of knowledge they have about contraceptives, there is quite an inconsistency between giving information and its utilization. Although the traditionally forbidden subjects of sex education and human sexuality are becoming more available, so that adolescents are being educated, the approach used in this education process does not seem to free the person being educated to utilize the knowledge given. Evidently, sheer factual data is nọt effective in preventing unwanted pregnancies. A more personal, open and confidential way of giving and receiving contraceptive information is necessary. This perspective of communication must involve more than showing movies and giving factual descriptions of the various methods. This would be an extremely important point of departure for further study. 
LIST OF FOOTNOTED REFERENCES

Claman, David, Barry Williams, and L. Wogan. "Reaction of Unmarried Girls to Pregnancy," Canadian Medical Association, CI (1969), 240-241.

Conne11, Elizabeth B. and Linbania Jacobson. "Pregnancy, The Teenager and Sex Education," American Journal of Public Health, XL.

Couch, Gertrude B. "Youth Looks at Sex," The Journal of School Hea1th, XXXVII (May, 1967), 333-338.

Droegemualler, William, Richard Florio, E. Steward Taylor. "The Second Year's Experience with Colorado's Abortion Law," American Journal of Obstetrics and Gynecology, CIX (March 15, 1971), 957-958.

Fields, George L. and Frida G. Surawicz. "A Review of Therapeutic Abortions at a Southern University Hospital," The Woman Physician, XXVI (August, 1971) 414-416.

Foster, Gred R. "Sex Information Vs. Sex Education: Implications for School Health," The Journal of School Health, XXXVII (May, 1967), 248-250.

Ha11, Earl Warren. Social and Health Needs in Childhood and Adolescence. California: University of California at Berkeley, 1972 .

Langmyhr, George and Walter C. Rogers. Legal Abortion: A Guide for Women in the United States. New York: Planned Parenthood, 1970 .

Looft, William R. "Sex Education for Parents," The Journal of School Health, XLI (October, 1971), 433-437.

Malo-Juvera, Dolores. "What Pregnant Teenagers Know About Sex," Nursing Outlook, XVIII (November, 1970), 32-35. 
Nathe, William and Ike E. Lacefield. Degree of Depression in Women Preceding Abortion at the University of Oregon Medical School, Graduate School of Social Work, Portland State University, Portland, Oregon, February 23, 1972.

Osofsky, Howard J., John Hagen, and Peggy Wood. "A Program for Pregnant Schoolgirls," American Journal of obstetrics and Gynecology, C (April 1, 1968), 1020-1027.

Pohlman, Edward and Julia Pohlman. The Psychology of Birth Planning. Massachusetts: Schenkman Publishing Company, Inc., 1969.

Potts, Malcolm. "Legal Abortions in the U.S.A.: A Preliminary Assessment," The Lancet, (September 18, 1971), 651-653.

Rauch, Joseph L., Lois B. Johnson, and Robert L. Burket. "The Management of Adolescent Pregnancy and Prevention of Repeat Pregnancies," HSMHA Health Reports, LXXXVIII (January, 1971), 66-73.

Sorrel, Philip N., Marshall Holley, and Gerald Anderson. "The Young Unwed Mother," Obstetrics and Gynecology, XXXII (December, 1968), 741-747.

Young, Robert D. "Sex, The Bible and Modern Man," The Journal of Schoo1 Hea1th, XL (December, 1970), 527-531. 
LIST OF RELATED READINGS

Ayd, Frank J. "The Teenager and Contraception," Pediatric Clinics of North America, XVI (May, 1969), 355-361.

"Editorial: The School-Age Pregnant Girl," The Journal of School Hea1th, XLI (September, 1971), 347-348.

Ebon, Martin, ed. Everywoman's Guide to Abortion. New York: Universe Books, 1971.

Grisez, Germain G. Abortion: The Myths, The Realities, and the Arguments. New York: Corpus Books, 1970.

Ha11, Robert E., ed. Abortion in a Changing World. New York: Columbia University Press, 1970.

Harrison, Colin P. "Teenage Pregnancy--Is Abortion the Answer?" Pediatric Clinics of North America, XVI (May, 1969), 363369 .

Holcomb, J. David, Arthur E. Garner, and Harper F. Beaty.

"Sex Education in Texas Public Schools," The Journal of School Health, XL (December, 1970), 563-566.

Howard, Marion. "Pregnant School-Age Girls," The Journal of School Health, XLI (September, 1971), 361-362.

Kaufman, Sherwin A. "When Teenagers Ask for the Pill," Family planning Perspectives, II (March, 1970), 49-52.

Levin, Max. "Healthy Sexual Behavior," Pediatric Clinics of North America, XVI (May, 1969), 329-332.

Murdock, C. George. "The Unmarried Mother and the School System," American Journial of Public Health, LVIII (December, 1968), 2217-2228.

Osofsky, Howard J. "Adolescent Out-of-Wedlock Pregnancy: An Overview, "Clinical obstetrics and Gynecology, XIV (June, 1971), $442-455$. 
"Adolescent Sexual Behavior: Current Status and Anticipated Trends for the Future," C1inical Obstetrics and Gynecology, XIV (June, 1971), 393-407.

Pakter, Jean, David Harris, and Frieda Nelson. "Surveillance of the Abortion Program in New York City: Preliminary Report," Clinical Obstetrics and Gynecology, XIV (March, 1971), 267-295.

Ingraham, Hollis and Robert Longood. "Abortion in New York State Since July 1970," Clinical Obstetrics and Gynecology, XIV (March, 1971), 5-24.

Pannor, Reuben. "The Teen-Age Unwed Father," Clinical Obstetrics and Gynecology, XIV (June, 1971), 466-472.

Patl, Stephen L., Richard G. Rappaport, and Peter Barglow. "Follow-Up of Therapeutic Abortion," Archives of General Psychiatry, XX (April, 1969).

Randa11, Alexander IV and J. Perlingiero Randall. "Sex Education in the Schools," Pediatric Clinic of North America, XVI (May, 1969), 371-377.

Rapoport, Judith. "American Abortion Applicants in Sweden," Archives of Genera1 Psychiatry, XIII (July, 1965), 24-33.

Russe11, J.K. "Pregnancy in the Young Teenager," The Lancet, I (February 15, 1969), 365-366.

Semmens, James P. and Kermit E. Krantz. The Adolescent Experience. London: The Macmillan Company, 1970.

Shea, Petrena A. "A Study of Girls 18 Years and Under Who Delivered Living Infants, Montgomery County, Maryland Residents 1967-1970," The Journal of School Health, XLI (October, 1971), 441-444.

Smith, Elizabeth Dorsey, Mary Veolitze, and Ruth Merkatz. "Social Aspects of Abortion Counseling for Patients Undergoing Elective Abortion," Clinical Obstetrics and Gynecology, XIV (March, 1971), 204-214. 


\section{APPENDIX I}

Private

Public Outside-in

A Descriptive Study of Educational Background, Contraceptive Knowledge, and Choice of Agency Among Selected Girls Under 18 years of Age Seeking an Abortion.

QUESTIONNAIRE - To be given by personal interview

1. Your age: a. $12-13 ;$ b. $14-15 ;$ c. $16-17 ; 18$

2. Are you in school? Yes No

Circle the highest grade completed: $\begin{array}{llllll}7 & 8 & 9 & 10 & 11 & 12\end{array}$

When did you last attend school on a full time basis?

Where did you go to school, or where will you go?

If the school is outside of Portland, what city is it in?

3. Parents' educational background?

Mother: a) did not graduate from high school

b) high school graduate

c) attended college

d) college graduate

e) post graduate

f) other, specify

Occupation Income 
Father: a) did not graduate from high school

b) high school graduate

c) attended college

d) college graduate

e) post graduate

f) other, specify

Occupation Income

4. Have there been any previous abortions within the immediate family?

Yes No Don't know If yes, specify:

5. Of the following methods of birth control, check those which you knew about before you came to the clinic and those you have used.

Method

Withdrawal

condom (rubber)

pil1

rhythm (safe period)

foam, jelly or cream

IUD, loop or coil

diaphram

douching

tubes tied

vasectomy

other
Know About Ever Used
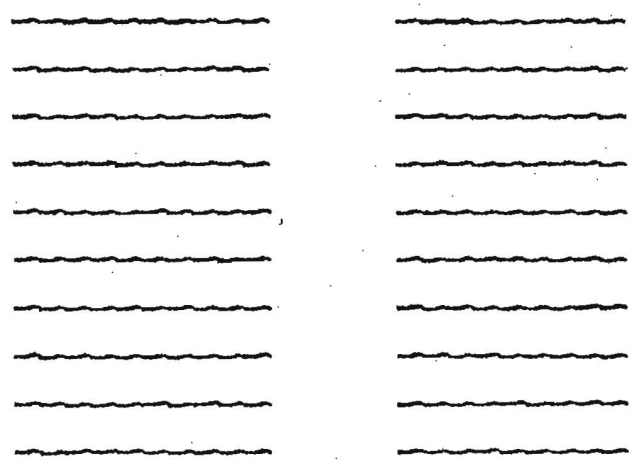

6. Check any of the following where you learned something about birth control.

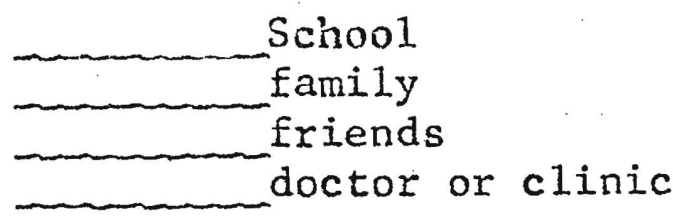

books or magazines social worker or counselor church other 
7. Have you ever done anything about obtaining contraceptives? Yes No

Specify if Yes:

Explain if No:

8. Did you use them? Yes No If No, why?

Emotional: a) other, specify

b) not romantic

c) too silly

d) too embarrassed

e) fear of cancer or similar disease

Factua1: a) did not understand directions

b) too new or unconventional

c) parent's disapproved

d) too expensive

9. Do you plan to use them? Yes No If No why:

Emotional: a) other, specify

b) not romantic

c) too silly

d) too embarrassed

e) fear of cancer or similar disease

Factual: a) did not understand directions

b) too new or unconventional

c) parent's disapproved

d) too expensive

10. From whom did you hear about this clinic?
a) family
b) Eriends
c) school
d) other agency or professional, specify
e) other, specify

11. What mide you actually choose this clinic? (Who talked to you about it?)
a) family 
b) friends

c) school

d) other agency or professional, specify

e) other, specify

12. If you had not been able to get an abortion, what would you do?

a) keep the baby

b) go to another place - clinic or doctor

c) give up the baby - adoption

d) have an illegal abortion

$*$ The interviewer must obtain specific and complete responses.

13. Is this a confirmed pregnancy? Yes No

14. Where was it confirmed? Specify:

15. Have you filled out a similar questionnaire previously?

Yes No 
EXACT RESIDENCE OF GIRLS ACCORDING

TO MOST RECENT SCHOOL ENROLLMENT

CORVALLIS H.S.

OREGON CITY H.S.

GRANTS PASS H.S.

JEFFERSON H.S.

HAWTHORNE H.S.-L.A. (at Reed College now)

DALLAS H.S., Dallas, Oregon

NORTH MARION H.S., Woodburn

LEBANON UNION H.S.

THRUSTON H.S., Springfield

PORTLAND COM. COL.

SAM BARLOW H.S., Gresham

MOLLALA UNION H.S., Mollala

WILLAMETTE LEARNING SCHOOL Portland

WARRENTON H.S., Astoria

SUNSET H.S., Beaverton

ASTORIA JR. H.S., Astoria

NR

Cleveland H.S., Portland

NR

WILLAMINA H.S., Willamina

WILSON H.S.
COLTEN H.S., Colten

FRANKLIN H.S., Portland

CLACKAMAS H.S., Clackamas

WARRENTON H.S., Warrenton

JACKSON H.S.

SEASIDE UNION, Seaside

GRESHAM H.S.

HOOD RIVER VALLY H.S., Hood Riv.

JUDSON JR. H., Salem

HOOD RIVER JR. H., Hood Riv.

MARSHALL H.S., Portland.

MADISON H.S., Portland

MARK MORRIS H.S., Longview

SANTIAM H.S., Mil1 City

WAHTONKA H.S., Da1las

MARSHALL H.S., Portland

GRESHAM H.S., Gresham

FRANKLIN H.S., Portland

ESTACADA JR. H., Estacada 
